DR RICHARD EDWARD WATCHORN (Orcid ID : 0000-0001-8337-2501)

Article type : Research Letter

\title{
Keratoacanthoma management: results of a survey of UK dermatologists and surgeons
}

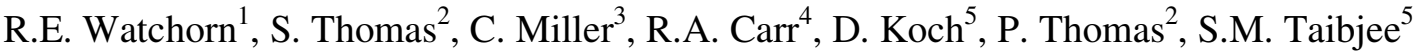 \\ 1. Department of Dermatology, Royal Devon \& Exeter Hospital, Exeter, UK. \\ 2. Clinical Research Unit, Faculty of Health and Social Sciences, Bournemouth University, Bournemouth, \\ UK. \\ 3. Research \& Development, Dorset County Hospital, Dorchester, UK. \\ 4. Department of Histopathology, Warwick Hospital, Warwick, UK. \\ 5. Department of Dermatology, Dorset County Hospital, Dorchester, UK.
}

Email: rwatchorn@gmail.com

Keywords: $\quad$ keratoacanthoma, squamous cell carcinoma, survey, united kingdom, views, management, questionnaire

Sources of funding: None

Conflicts of interests: None declared

Dear Editor,

Distinction of keratoacanthoma (KA) from squamous cell carcinoma (SCC) is challenging. Management is controversial, with some advocating prompt surgical excision and others monitoring to allow for spontaneous resolution ${ }^{1}$. The controversy is compounded by rare reports of metastasis ${ }^{2}$. And yet the benign natural history of KA is supported by various studies, including a systematic review of 455 cases with no cases of metastasis or death ${ }^{1}$, and observational studies confirming spontaneous resolution ${ }^{1}$. Unlike in SCC, perineural or venous invasion in KA is not associated with adverse outcome ${ }^{3,4}$. Comparative genomic hybridisation and DNA microarray studies indicate that KA and SCC are genetically distinct. ${ }^{5,6}$ Some have suggested that the rare reports of metastatic KA may have instead arisen from SCC development within $\mathrm{KA}^{3}$.

An online 22-item questionnaire designed by dermatologists and researchers, ascertained clinicians' views about KA and its management, previously observed outcomes and willingness to enrol patients into a proposed clinical trial. The questionnaire was circulated via the British Association of Dermatologists (BAD), the British Society for Dermatological Surgery (BSDS), Reconstructive Surgery Trials Network (RSTN), UK Dermatology Clinical Trials Network (UKDCTN) and the national trainee electronic mailing list. Of 223 respondents $162(73 \%)$ were consultants. Responses to a subset of questions were compared

This article has been accepted for publication and undergone full peer review but has not been through the copyediting, typesetting, pagination and proofreading process, which may lead to differences between this version and the Version of Record. Please cite this article as doi: $10.1111 / \mathrm{bjd} .15858$

This article is protected by copyright. All rights reserved. 
between specialties (dermatology [ $\mathrm{n}=152]$, dermatological surgery [ $\mathrm{n}=48]$, and plastic surgery $[n=21]$ ) (chi-squared or Fisher's exact test (IBM SPSS Version 22).

While twenty-six (12\%) respondents considered KA and SCC to be clinically and histologically indistinguishable, the majority $(194,87 \%)$ regarded them as distinct $(13 \%)$ or likely distinct (74\%). Only 28 (13\%) felt that conservative management (e.g. clinical observation and/or shave excision) could be considered. Most $(166,74 \%)$ felt that KA should be managed as for SCC, as spontaneous resolution cannot be reliably predicted nor SCC reliably excluded. Dermatological surgeons were more likely $(23 \%)$ than dermatologists $(10 \%)$ or plastic surgeons $(0 \%)(\mathrm{p}=0.03)$ to regard them as indistinguishable.

Twenty-one (9\%) reported that they had observed local recurrence of KA, while 4 (2\%) reported having observed metastasis.

A photograph of a typical KA-like lesion was presented with three scenarios of lesion behaviour (reducing in size/static/enlarging) over a hypothetical preceding four-week period. For each, respondents could choose multiple management options (see Table 1A). There were no statistically significant differences between specialties ( 24 tests all with $\mathrm{p}>0.05$ ). In the case of the involuting scenario, around $35 \%$ selected clinical observation, and around a half excision. When the lesion was static or enlarging, surgical excision was favoured.

The majority $(74 \%, 166)$ reported not deferring surgery for KA-like lesions while 26\% (57) reported doing so, with no significant between-specialty differences apparent $(\mathrm{p}=0.40)$. Comments indicated that even if not intended, deferral frequently occurs due to waiting lists. One hundred and forty-two (68\%) indicated a willingness to routinely observe KA-like lesions if a clinical trial were to confirm spontaneous resolution in a proportion of cases (Table $2 \mathrm{~A}$ - supplementary material).

One hundred and twenty-five (56\%) declared that anatomical site did not influence management, although the clinical vignettes indicated a lower inclination to excise involuting lesions on the lower leg compared with the ear.

Over a half indicated willingness to enrol patients with KA-like lesions into a UK multicentre clinical trial (table 1b(i)).

Around a half (Table 1Bii) were willing to enroll patients into a suggested trial design which incorporated a 4- to 5-week initial clinical observation period to establish the growth phase of the lesion, but ensuring risk minimisation by promptly excising all enlarging lesions within 31/62 day NHS cancer targets. Table 1B).

Suggested exclusion criteria included immunosuppression, genetic disorders (e.g. xeroderma pigmentosum), disputed clinical diagnosis, previous SCC, and high risk or cosmetically sensitive sites (Table 2B - supplementary material).

Inclusion of an initial incisional biopsy reduced clinician willingness to enrol patients. Reasons cited included surgical capacity or duplication of surgery, and concerns over the adequacy of partial biopsy for histological KA diagnosis. (Table 2B - supplementary material). One respondent highlighted the possible confounding impact of biopsy, citing high regression rates of KA following incisional biopsy ${ }^{7}$.

This article is protected by copyright. All rights reserved. 
For lesions static in size after 4-5 weeks' observation, 70 (33\%) were willing to shave excise, $84(40 \%)$ were not and 57 (27\%) were uncertain (Table 1Biv). Comments highlighted concerns over potential under-treatment of SCC and uncertainty regarding adequacy of shave excision for histological diagnosis. Others indicated a preference for curettage. A proposal to randomise patients with static lesions to either shave or surgical excision did not increase recruitment willingness. (Table $1 \mathrm{Bv}$ ).

Ninety (41\%) indicated their local histopathologists distinguish KA from SCC, 27 (12\%) indicated that they do not and the remainder $(101,46 \%)$ noted variation. In a UK histopathology department survey, the ratio of coded SCC to KA varied from 2.5:1 to 139:1 confirming widespread reporting variations ${ }^{8}$. In a clinical trial, centralised expert histopathologist review could overcome this issue. Of note, central review of SCC histology specimens led to reclassification as KA in up to $94.4 \%$ of cases in two phase II vemurafenib trials ${ }^{4}$.

Our survey demonstrates significant clinical equipoise in the management of KA-like lesions amongst UK clinicians and confirms a willingness to enrol patients in a clinical trial, while highlighting the need to mitigate against under-treatment of any potential SCC within the trial design.

\section{Acknowledgements}

We wish to thank Dermatologists from Exeter and Warwick, Prof Hywel Williams, Mr Abhilash Jain, and Mr Matthew Gardiner for their advice and assistance with this survey.

1. Savage JA, Maize JC Sr. Keratoacanthoma clinical behavior: a systematic review. Am J Dermatopathol 2014;36;422-429.

2. Hodak E, Jones RE, Ackerman AB. Solitary keratoacanthoma is a squamous-cell carcinoma: three examples with metastases. Am J Dermatopathol 1993;15:332-42; discussion 343-52.

3. Weedon DD, Malo J, Brooks D, Williamson R. Keratoacanthoma: is it really a variant of squamous cell carcinoma? ANZ J Surg 2010;80:129-130.

4. Selmer J, Skov T, Spelman L, Weedon D. Squamous cell carcinoma and keratoacanthomas are biologically distinct and can be diagnosed by light microscopy: a review. Histopathology 2016;69:535-41.

5. Li J, Wang K, Gao F, Jensen TD, Li ST, DeAngelis PM, Kølvraa S, Proby C, Forslund O, Bolund L, Clausen OP. Array comparative genomic hybridization of keratoacanthomas and squamous cell carcinomas: different patterns of genetic aberrations suggest two distinct entities. J Invest Dermatol 2012;132:2060-6.

6. Ra SH, Su A, Li X, Zhou J, Cochran AJ, Kulkarni RP, Binder SW. Keratoacanthoma and squamous cell carcinoma are distinct from a molecular perspective. Modern Pathology 2015;28:799-806.

7. Takai T, Misago N, Murata Y. Natural course of keratoacanthoma and related lesions after partial biopsy: clinical analysis of 66 lesions. J Dermatol 2015;42:353-62.

8. Carr RA, Houghton JP. Histopathologists' approach to keratoacanthoma: a multisite survey of regional variation in Great Britain and Ireland. J Clin Pathol 2014;67:637-8.

This article is protected by copyright. All rights reserved. 
Table 1

(a) Management choices for KA-like lesions on the ear and leg

\begin{tabular}{llcccc}
\hline $\begin{array}{l}\text { Lesion status \& } \\
\text { location }\end{array}$ & \multicolumn{4}{c}{$\begin{array}{c}\text { Treatment Approach } \\
\mathrm{N}(\%) \dagger\end{array}$} \\
\cline { 2 - 6 } & & $\begin{array}{c}\text { Incisional } \\
\text { biopsy }\end{array}$ & $\begin{array}{c}\text { Surgical } \\
\text { excision }\end{array}$ & Shave & $\begin{array}{c}\text { Clinical } \\
\text { observation }\end{array}$ \\
\hline Reducing in size & Ear & $28(13 \%)$ & $123(55 \%)$ & $0(18 \%)$ & $75(34 \%)$ \\
& Leg & $34(15 \%)$ & $96(43 \%)$ & $4(24 \%)$ & $80(36 \%)$ \\
\hline No change in size & Ear & $19(9 \%)$ & $195(87 \%)$ & $3(10 \%)$ & $9(4 \%)$ \\
for 4 weeks & Leg & $25(11 \%)$ & $181(81 \%)$ & $0(13 \%)$ & $9(4 \%)$ \\
\hline Increasing in size & Ear & $12(5 \%)$ & $207(93 \%)$ & $15(7 \%)$ & $0(0 \%)$ \\
\cline { 2 - 6 } & & $14(6 \%)$ & $211(95 \%)$ & L5 (7\%) & $1(0 \%)$ \\
\hline
\end{tabular}

tRespondents could choose more than one treatment approach, thus across categories percentages can sum to $>100 \%$

(b) Willingness to participate in UK multi-centre clinical study/trial, depending on trial design*

\begin{tabular}{|c|c|c|c|c|}
\hline & Yes & No & Unsure & $\begin{array}{c}\text { Total } \\
\text { Responses }\end{array}$ \\
\hline $\begin{array}{l}\text { General willingness } \\
\text { to participate }\end{array}$ & $128(58 \%)$ & 24 (11\%) & 70 (32\%) & 222 \\
\hline $\begin{array}{l}\text { b) Defined period of observation ( } 4-5 \\
\text { weeks), followed by: } \\
\text { - Excision of enlarging lesions } \\
\text { - Observation of involuting lesions }\end{array}$ & 106 (48\%) & $44(20 \%)$ & $71(32 \%)$ & 221 \\
\hline $\begin{array}{l}\text { c) Prior incisional biopsy and defined } \\
\text { period of observation ( } 4-5 \text { weeks): } \\
\text { - Excision of enlarging lesions or with } \\
\text { histology suggestive of SCC } \\
\text { - Observation of involuting lesions with } \\
\text { histology suggesting KA }\end{array}$ & 84 (39\%) & 74 (35\%) & 55 (26\%) & 213 \\
\hline $\begin{array}{l}\text { d) As for b), but shave for static lesions } \\
\text { (subsequent excision if recurrence, or if } \\
\text { histology suggests SCC) }\end{array}$ & 70 (33\%) & 84 (40\%) & 57 (27\%) & 211 \\
\hline $\begin{array}{l}\text { e) As for b), but static lesions randomised } \\
\text { to either shave or excision } \\
\text { (subsequent excision of shaved lesions if } \\
\text { recurrence, or if histology suggests SCC) }\end{array}$ & 69 (33\%) & 75 (36\%) & 67 (32\%) & 211 \\
\hline
\end{tabular}

${ }^{\star}$ Figures rounded up to nearest \%; may not add up to $100 \%$

This article is protected by copyright. All rights reserved. 